\title{
By-Catch of franciscana Pontoporia blainVillei in Uruguayan artisanal GILLNET FISHERIES: AN EVALUATION AFTER A TWELVE-YEAR GAP IN DATA COLLECTION ${ }^{1}$
}

\author{
Valentina Franco-Trecu ${ }^{2},{ }^{*}$, Paula Costa, Carolina Abud ${ }^{2}$, \\ Caterina Dimitriadis ${ }^{2}$, Paula Laporta ${ }^{2}$, Cecilia Passadore² and María Szephegyi ${ }^{2}$
}

\begin{abstract}
Aвsтract: The franciscana dolphin (Pontoporia blainvillei) is the most threatened small cetacean in the southwestern Atlantic Ocean. Its incidental capture in the Uruguayan fisheries of the Atlantic oceanic coast (AOC) has been recorded since 1940 and was systematically studied from 1974 to 1994, providing the most recent by-catch per unit of effort estimate (BPUE) for the AOC region (0.0064 franciscanas per $1000 \mathrm{~m}$ net per fishing set). The lack of new by-catch data during the past 12 years has led to a data gap in by-catch estimates for the species in Uruguay. The current study was developed in two separate stages, a first stage (July 2004 - December 2005) designed to identify fisheries that interact with franciscana, and a second stage (2006), designed to determine new BPUE and franciscana mortality estimates for the selected fisheries. During the first stage, 13 artisanal fisheries of the Uruguayan coast were visited monthly, while in the second stage five fisheries (including the Rio de la Plata estuary and the AOC) were selected for monitoring. During 2006, 26 fishermen recorded all the information related to each fishing event, allowing the estimation of fishing effort calculated in linear units multiplied by hour $\left(\mathrm{FE}_{\mathrm{L}}\right)$. We also estimated a fishing set $\left(\mathrm{FE}_{\mathrm{S}}\right)$ based by-catch rate which allowed the comparison with previously reported results. For 2006, the $\mathrm{BPUE}_{\mathrm{L}}$ (based on $\mathrm{FE}_{\mathrm{L}}$ ) was estimated at 0.0020 franciscanas per $1000 \mathrm{~m}$ net per hour and the BPUE at 0.0286 franciscanas per $1000 \mathrm{~m}$ net per fishing set. The $\mathrm{BPUE}_{\mathrm{L}}$ was extrapolated to the surveyed fishing fleets during 2006, resulting in a mortality estimate of 289 (95\% CI: 266-350) franciscanas. Based on the fishing dynamics reported herein, we consider the BPUE the most accurate estimate of by-catch for the Uruguayan coast. This research updates the values of BPUE in the AOC after a 12-year information gap and includes the first by-catch evaluation in the Uruguayan estuarine coast. We highly recommend an abundance estimation of the species to complement the information reported herein in order to know the current status of franciscana dolphin population in Uruguay.
\end{abstract}

Resumen: El delfín franciscana (Pontoporia blainvillei) es el pequeño cetáceo más amenazado de Atlántico Sudoccidental. La captura incidental de franciscanas en las pesquerías uruguayas de la costa del Océano Atlántico (AOC) ha sido registrada desde 1940 y relevada sistemáticamente entre 1974 y 1994; brindando el último valor de Captura Por Unidad de Esfuerzo (BPUE) en la AOC uruguaya (0,0064 franciscanas por $1000 \mathrm{~m}$ de red por lance). La ausencia de nuevos valores de BPUE durante 12 años produjo una carencia de datos sobre la captura incidental de la especie en Uruguay. El presente estudio fue realizado en dos períodos, el primero (Julio 2004-Diciembre 2005) con el objetivo de identificar las pesquerías que interactuaban con la franciscana, y el segundo período (año 2006) para determinar la BPUE y mortalidad de la franciscana en las pesquerías seleccionadas. En el primer período se visitaron mensualmente 13 pesquerías artesanales de la costa uruguaya, mientras que en el segundo se monitorearon cinco de ellas (incluyendo el estuario del Río de la Plata y la AOC). Durante el 2006, 26 pescadores registraron todos los datos de cada evento de pesca, permitiendo la estimación del esfuerzo pesquero calculado en unidades lineales por hora $\left(\mathrm{FE}_{\mathrm{L}}\right)$. Además, para comparar nuestros resultados con los previamente reportados, estimamos una tasa de captura incidental por eventos de pesca $\left(\mathrm{FE}_{\mathrm{S}}\right)$. Para el año 2006, el valor de BPUE (basada en $\mathrm{FE}_{\mathrm{L}}$ ) fue 0,0020 franciscanas cada $1000 \mathrm{~m}$ de red por hora y el de $\mathrm{BPUE}_{\mathrm{S}}$ fue 0,0286 franciscanas por $1000 \mathrm{~m}$ de red por evento de pesca. El BPUE $\mathrm{L}_{\mathrm{L}}$ fue extrapolado a la flota de las pesquerías relevadas durante 2006, resultando en una mortalidad de 289 (95\% IC: 266-350) franciscanas. Debido a la dinámica pesquera aquí presentada, consideramos que el valor de BPUE $\mathrm{L}_{\mathrm{L}}$ es el más adecuado para la costa uruguaya. Este trabajo actualiza la BPUE en la AOC luego de 12 años de ausencia de datos e incluye por primera vez la evaluación de las capturas de franciscana en la costa estuarina uruguaya. Es altamente recomendable estimar la abundancia de la especie para complementar la información aquí reportada y conocer su estado de conservación en Uruguay.

KeYwords: Atlantic Ocean, Río de la Plata, Uruguayan coast, franciscana dolphin, Pontoporia blainvillei, by-catch, artisanal fishery, gillnet, mortality

\section{Introduction}

The franciscana (Pontoporia blainvillei) is an endemic dolphin of the coasts of Brazil, Uruguay and Argentina. It inhabits waters from shore to $55 \mathrm{~km}$ offshore and up to a water depth of $40 \mathrm{~m}$ (Pinedo et al., 1989), or 60m off Rio de Janeiro, Brazil (Danilewicz et al., 2002). These are the main areas of operation of the artisanal and industrial coastal fishing fleets. Recent evaluations of the franciscana status point out that the reported bycatch values are not sustainable (Secchi, 1999; Kinas, 2002; Secchi and Wang, 2002; Secchi et al. 2003; Reeves et al., 2008 ${ }^{3}$ ). Because of this, the franciscana is currently considered the most endangered small cetacean in the southwestern Atlantic Ocean (Praderi et al., 1989; Crespo, 20004), with an estimated mortality of roughly

\footnotetext{
${ }^{1}$ Received on 23 March 2009. Accepted on 3 September 2009. Managed by Daniel Palacios.

${ }^{2}$ Proyecto Franciscana/Cetáceos Uruguay, Sección Etología - Facultad de Ciencias, Universidad de la República, Iguá 4225, CP 11400, Montevideo, Uruguay.

* Corresponding author, e-mail: franciscana@fcien.edu.uy.

${ }^{3}$ Reeves, R.R., Dalebout, M.L., Jefferson, T.A., Karczmarski, L., Laidre, K., O'Corry-Crowe, G., Rojas-Bracho, L., Secchi, E.R., Slooten, E., Smith, B.D., Wang, J.Y., Zerbini, A.N. and Zhou, K. (2008) Pontoporia blainvillei. In: IUCN 2008. 2008 IUCN Red List of Threatened Species. <www.iucnredlist.org>

${ }^{4}$ Crespo, E.A. (2000) Report of the Third Workshop for Coordinated Research and Conservation of the Franciscana Dolphin (Pontoporia blainvillei) in the Southwestern Atlantic. Reported to the Convention of Migratory Species (UNEP), June 1998, Bonn, Germany, Unpublished. 23p.
} 
2800 individuals per year along its distribution range (Ott et al., 2002; Secchi et al., 2003). Considering that this species, like other large vertebrates, has a low reproductive potential, high by-catch rates might cause population decline and increase the risk of extinction (Secchi et al., 2002). Since 2008, the species has been classified as vulnerable throughout its entire distribution range (Reeves et al., 2008).

For the Uruguayan fisheries, the earliest records of franciscana by-catch date back to 1940 and are related to the development of shark fisheries in Punta del Diablo (Van Erp, 1969). During the first systematic study carried out in the five most important fisheries of the Atlantic Ocean coast (AOC) (La Paloma, Cabo Polonio, Valizas, Punta del Diablo and La Coronilla; see Figure 1) from 1974 to 1994, annual by-catch records for franciscanas ranged from 418 individuals in 1974 to 66 in 1994 (Praderi, $1997^{5}$ ) (see Table 1). The highest values of incidental mortality were recorded in Punta del Diablo and Valizas, where the highest fishing effort was recorded.

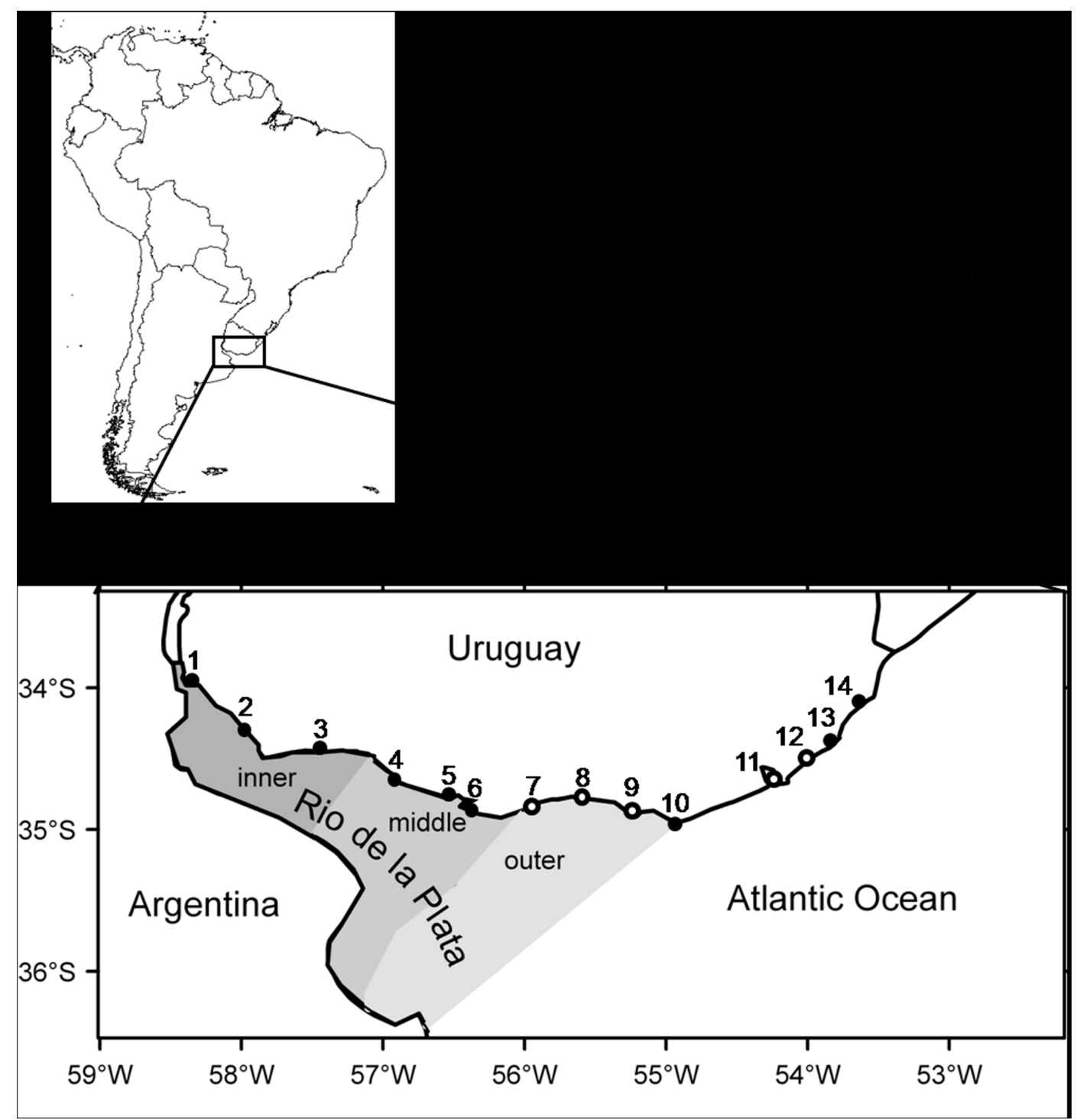

Figure 1. Map showing the artisanal fisheries monitored along the Uruguayan coast (numbers between brackets indicate fishermen contacted exclusively in the first stage of this study). 1:Carmelo (4), 2: Colonia (3), 3: Juan Lacaze (4), 4: Kiyú (4), 5: Playa Pascual (2), 6 : Pajas Blancas, 7: Neptunia, 8: San Luis, 9: Piriápolis, 10: Punta del Este (5), 11: La Paloma, 12: Cabo Polonio, 13: Valizas (6) and 14: Punta del Diablo (5). White dots show localities surveyed in the second stage of the study.

${ }^{5}$ Praderi, R. (1997) Análisis comparativo de estadísticas de captura y mortalidad incidental de Pontoporia blainvillei en Uruguay durante 20 años. Pages 42-53 in Pinedo, M. C. and Barreto, A. S. (Eds) Anais do $2^{\circ}$ Encontro sobre Coordenação de Pesquisa e Manejo da Franciscana. 1994. FURG: Rio Grande, Brazil. 
Franciscana by-catch in the Uruguayan AOC was higher in summer (November-February), when large mesh nets were used near shore at depths between 10 and $20 \mathrm{~m}$ (Praderi, 1997). To date, two studies addressing values of by-catch per unit of effort (BPUE) have been conducted for the Uruguayan AOC. The first one was recorded for the periods 1975-1978 and 1980-1982, with a maximum BPUE value of 0.0055 franciscanas per $1000 \mathrm{~m}$ of net per fishing set (mean $=0.0038$, standard deviation $=0.0012$ ) recorded during 1981 (Crespo et al., $1986^{6}$ ) (Table 1). The second by-catch estimate of 0.0064 franciscanas per $1000 \mathrm{~m}$ of net per day was obtained from a review of 20 years of information (1974-1994), representing the most recent BPUE value for Uruguay (Ott et al., 2002).

As the last study to estimate franciscana by-catch in fisheries in Uruguay was conducted more than 12 years ago (Praderi, 1997), current levels of incidental catches of the franciscana are unknown and it is difficult to evaluate the status of the population inhabiting the Uruguayan coast. Such lack of information was mentioned in the most recent regional workshops on the Biology and Conservation of franciscana dolphin (Crespo, 2000; Secchi et al., 2002). Furthermore, there are many artisanal fisheries along the Río de la Plata coast of Uruguay (Galli, 20007; Norbis and Verocai, 2001) for which interactions with franciscana have never been evaluated.
Hence, the aims of this study are i) to identify the Uruguayan artisanal gillnet fisheries of the Río de la Plata estuary (RPE) that interact with the franciscana dolphin; and ii) to determine the by-catch rates and annual mortality of franciscanas in the RPE and AOC.

\section{Material and Methods}

Study area

The study area encompasses $500 \mathrm{~km}$ of the Uruguayan coast, including the RPE and the AOC (Figure 1). The Río de la Plata $\left(34^{\circ} 00^{\prime}-36^{\circ} 10^{\prime} \mathrm{S}, 5^{\circ} 00^{\prime}-58^{\circ} 10^{\prime} \mathrm{W}\right)$ is a coastal plain estuary draining the second largest basin of South America (Guerrero et al., 1997; Mianzan et al., 2001). It has a wide mouth where no barriers such as cliffs or hills exist, so the action of winds, waves, tides and currents are significant, inducing the mixing of seawater and freshwater (Boschi, 1988). Considering its main features and dynamics, the system can be classified into three zones: the inner, middle and outer Río de la Plata (see Figure 1), which can fluctuate and overlap depending on the dominant wind and river discharge. The inner section of Río de la Plata is located on the west side of the Uruguayan coast and it is characterized by the dominance of freshwater; the oceanic influence can be detected only by the presence of tidal fluctuations.

Table 1. Numbers of franciscana dolphins incidentally caught and values of by-catch per unit of effort (BPUE; when were available) in the artisanal gillnet fishery of the Atlantic Ocean coast (AOC) between 1969 and 1994 and for the present study (2006). BPUE data are presented as linear values $(1000 \mathrm{~m}$ of net set per day).

\begin{tabular}{|c|c|c|c|}
\hline YEAR & $\begin{array}{l}\text { FRANCISCANA DOLPHIN } \\
\text { INCIDENTALLY CAUGHT }\end{array}$ & $\begin{array}{c}\text { AOC BPUE (FRANCISCANAS/ } \\
\text { 1000m OF NET X DAY) }\end{array}$ & SOURCE \\
\hline 1969 & About 1500 & - & $\begin{array}{l}\text { Brownell and Ness, } 1970^{1} \\
\end{array}$ \\
\hline 1970 & About 2000 & - & Pilleri, 1971 \\
\hline $1971-1973$ & 536 & - & Brownell and Praderi 1974²; Brownell 1975 \\
\hline 1974 & 418 & - & Praderi, 1997 \\
\hline 1975 & 225 & 0.0033 & Crespo et al., 1986 \\
\hline 1976 & 243 & 0.0025 & Crespo et al., 1986 \\
\hline 1977 & 254 & 0.0039 & Crespo et al., 1986 \\
\hline 1978 & 254 & 0.0027 & Crespo et al., 1986 \\
\hline 1980 & 120 & 0.0032 & Crespo et al., 1986 \\
\hline 1981 & 160 & 0.0055 & Crespo et al., 1986 \\
\hline 1982 & 165 & 0.0052 & Crespo et al., 1986 \\
\hline 1994 & 66 & - & Praderi, 1997 \\
\hline 1974-1994 & 1905 & 0.0064 & Ott et al., 2002 \\
\hline 2006 & 80 & 0.0272 & This study \\
\hline
\end{tabular}

${ }^{1}$ Brownell, R. L. Jr. and Ness, R. (1970) Preliminary notes on the biology of the franciscana, Pontoporia blainvillei, (Cetacea: Platanistidae). Pages 23-28 in Proceedings of the Sixth Annual Conference on Biological Sonar Diving Mammals 1969, Stanford Research Institute: Menlo Park, USA.

${ }^{2}$ Brownell, R. L. Jr. and Praderi, R. (1974) Present research and conservation problems with the Franciscana, Pontoporia blainvillei, in Uruguayan waters. ACMRR/FAO/Doc.23, December 16-19. La Jolla, California, USA.

\footnotetext{
${ }^{6}$ Crespo, E.A., Perez Macri, G. and Praderi, R. (1986) Estado actual de la población de Franciscana, Pontoporia blainvillei en las costas uruguayas. Pages 92-105 in Castello, H.P. (Ed.) Actas I Reunión de Trabajo de Expertos en Mamíferos Acuáticos de América del Sur, Buenos Aires.

${ }^{7}$ Galli, O. (2000) Pesca y seguridad alimentaria. Propuesta de ordenación de las pesquerías costeras y de la plataforma continental. In REDES Red de ecología social amigos de la Tierra: Uruguay Sustentable, una propuesta ciudadana. Montevideo, Uruguay. 523p.
} 
In the middle section, the marine influence is detected by changes in tides, waves, and salinity, being the inner limit of salt intrusion. The outer Río de la Plata extends from Punta Rasa, Argentina, northwards to Punta del Este, Uruguay. This section is highly dynamic, with salinity varying from 5 to $30 \mathrm{ppm}$, and is greatly influenced by the adjacent Atlantic Ocean (Boschi, 1988; Guerrero et al., 1997). This whole system constitutes the spawning and breeding area for many invertebrate and fish species (Macchi et al., 1996,; Acha et al., 1999; Macchi and Acha, 2000; Vizziano et al., 2001; Macchi et al., 2003), including the whitemouth croaker (Micropogonias furnieri), which is the most commercially important coastal fish in the region (Norbis et al., 1992; Acuña et al., 1996) and spawns between October and March in the middle Río de la Plata (Macchi et al., 1996; Jaureguizar et al., 2003).

In the adjacent Atlantic coast, wind regimes, river discharge and the displacement of the Brazil-Malvinas Confluence generate seasonal variability, with cold and nutrient-rich sub-Antarctic waters dominating in winter, and warm, nutrient-poor sub-tropical waters during summer (Piola et al., 2000; Ortega and Martínez, 2007). The confluence of these two currents produces one of the most energetic and productive regions in the world supporting large fisheries (Guerrero et al., 1997; Ortega and Martínez, 2007; Lopes et al., 2006).

\section{Sampling design}

Surveys took place from July 2004 to December 2006 and were divided into two stages, according to the aims of the study. During the first stage (July 2004 - December 2005), 13 artisanal gillnet fisheries were visited on a monthly basis along $500 \mathrm{~km}$ of the Uruguayan coast. Nine fisheries were located along the coast of the RPE, including the inner (Figure 1: localities 1-3), middle (Figure 1: localities 4-6); and external Río de la Plata (Figure 1: localities 8-10). Four fisheries were located along the AOC (Figure 1: localities 11-14).

During each visit of the first stage, fishermen were asked about their fishing activities (fishing equipment used, fishing grounds, and target species) and whether they were aware of franciscana or had ever incidentally caught this species (specifying relevant data such as date, place, depth, and nets used). The first stage was very important for this research because the researchers were able to learn about the fisheries dynamics along the entire Uruguayan coast and to get to know the fishermen and their perceptions regarding the franciscana dolphin. It was also essential to explain in detail to the fishermen the goals of the following stage; to train them to obtain the information needed for the second stage as well as to gain their confidence and commitment to cooperate with the second stage of the investigation. The information gathered during this stage allowed the selection of a subset of fisheries to work with during the second stage, based on fishing frequency, strategy, and their knowledge of the species and by-catch frequency (as indicators of franciscana presence in the fishing area).

In the second stage (January - December 2006), the five selected gillnet fishing localities were monitored on a monthly basis. Three were located along $120 \mathrm{~km}$ of the RPE (Pajas Blancas, San Luis and Piriápolis) (Figure 1: 6, 8 and 9) and two (La Paloma and Cabo Polonio) were located along $160 \mathrm{~km}$ of the AOC (Figure 1: 11 and 12). In the first month, we obtained details from the fishermen on vessel characteristics (length, motor, gross registered tonnage, number of fishermen). Also, a logbook was given to each fisherman, who recorded the fishing operations including date, fishing grounds, characteristics of the gear used (number of nets, length, height, mesh size), setting details (duration, depth and approximate distance from the coast), and catches of both fish $(\mathrm{kg})$ and franciscanas (number). Researchers copied the data from logbooks during each visit, but never took the logbook away from fishermen, allowing them to have records of all fishing operations. Camera and films were also given to the fishermen in order to record events of dolphin interaction and fishing operations. In the results section (Fisheries description) the monitored fisheries during the second stage are described in detail (Table 2).

\section{Data analysis}

Based on data from logbooks gathered during the second stage, fishing effort (FE) and franciscana BPUE were calculated using two different approaches: one considering total length of net and soaking time (expressed as $1000 \mathrm{~m}$ of net per hour; denoted as $\mathrm{FE}_{\mathrm{L}}$ and $B P U E_{L^{\prime}}$ respectively) and another based on the number of fishing sets, determined as the total length of nets set per fishing event (expressed as $1000 \mathrm{~m}$ of net per set, denoted as $\mathrm{FE}_{\mathrm{S}}$ and $\mathrm{BPUE}_{\mathrm{S}^{\prime}}$ respectively) (Table 3). The $\mathrm{BPUE}_{\mathrm{S}}$ was calculated in order to compare our results with those previously reported for Uruguay and other areas (Crespo et al., 1986; Praderi et al., 1989; Secchi et al., 1997; Cappozzo et al., 2000; Corcuera et al., 2000'; Ott et al., 2000¹0; Di Beneditto, 2003; Secchi et al., 2004).

\footnotetext{
${ }^{8}$ Cappozzo, H.L., Monzón, F., Pérez, J.E., Albareda, D. and Corcuera, J.F. (2000) Mortalidad del delfín Franciscana Pontoporia blainvillei en la Provincia de Bs.As. Reporte Técnico WP24 presentado para el IV Workshop para a Coordinação da Pesquisa e Conservação da Franciscana, Pontoporia blainvillei, no Atlântico Sul Ocidental. 5-9 Noviembre, Porto Alegre, Brasil.

${ }^{9}$ Corcuera, J.F., Monzón, I., Cornejo, J., Pérez, A., Beilis, M., Gingarelli, D., Albareda, D. and Arias, M. (2000) Mortalidad de Pontoporia blainvillei en el norte de la Provincia de Buenos Aires. Pages 75-80 in UNEP/CMS (Eds) Report of the Third Workshop for Coordinated Research and Conservation of the Franciscana Dolphin (Pontoporia blainvillei) in the Southwestern Atlantic. 2000. UNEP/CMS, Bonn, Germany. ${ }^{10} \mathrm{Ott}$, P.H., Moreno, I.B. and Danilewicz, D.S. (2000) Estimativa da mortalidade anual de Pontoporia blainvillei nas comunidades pesqueiras do litoral norte do Rio Grande do Sul, sul do Brasil. Pages 65-67 in UNEP/CMS (Eds) Report of the Third Workshop for Coordinated Research and Conservation of the Franciscana Dolphin (Pontoporia blainvillei) in the Southwestern Atlantic. 2000, UNEP/CMS, Bonn, Germany.
} 


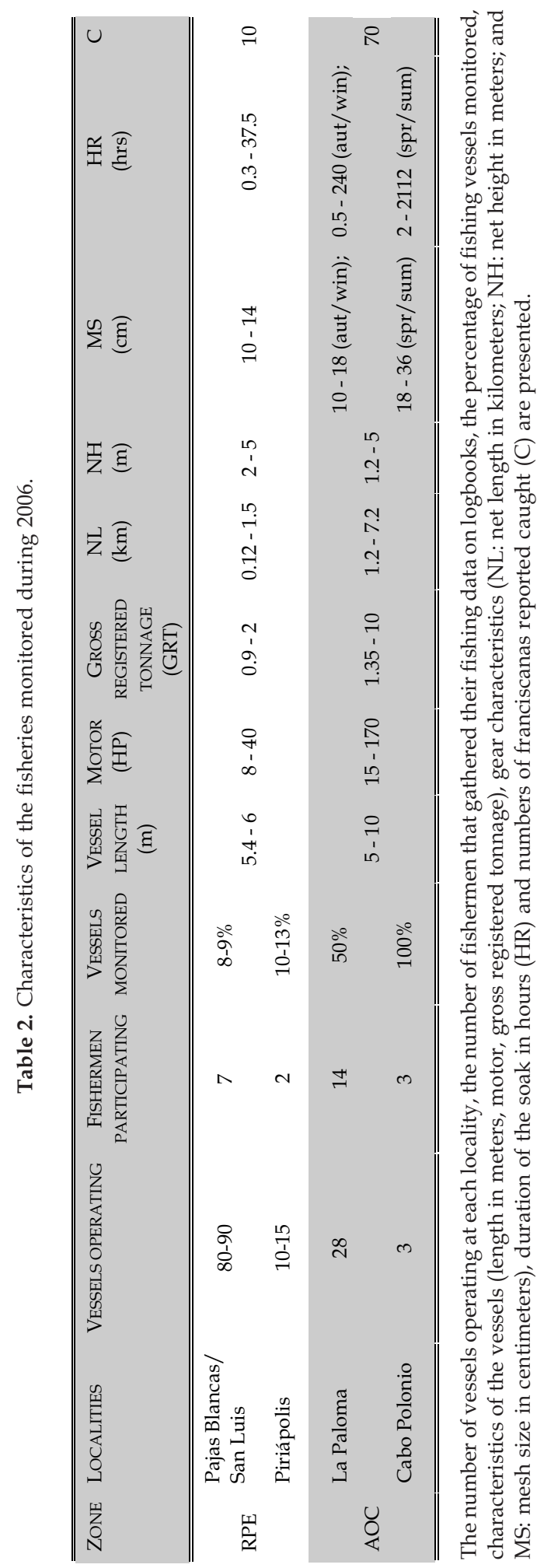

BPUE was calculated as the number of franciscanas caught divided by the fishing effort (Table 3). For all BPUE we estimated standard errors based on bootstrap (Efron and Tibshirani, 1993) of the observed data with replacement using 1000 replicates.

Values of annual and seasonal franciscana by-catch, $\mathrm{FE}_{\mathrm{L}^{\prime}}$ $\mathrm{FE}_{\mathrm{S}^{\prime}} \mathrm{BPUE}_{\mathrm{L}}$ and $\mathrm{BPUE}_{\mathrm{S}}$ for the RPE, the AOC and the entire Uruguayan coast were calculated for nets with different mesh sizes (Table 3 and 4). As no extrapolation was done for the non-monitored fisheries of the second stage, it is important to keep in mind that the values presented herein as from RPE were calculated using logbooks of Pajas Blancas/San Luis, Neptunia and Piriápolis fishermen. Similarly, those results referred to as AOC were calculated using logbooks of La Paloma and Cabo Polonio fishermen and the ones for the entire Uruguayan coast were calculated based only on the five fisheries mentioned above.

Relative frequencies of franciscana by-catch and $\mathrm{FE}_{\mathrm{L}}$ were analyzed according to distance from the coast and depth (Figure 2). For the analyses, seasons were defined as follows: summer, from 22 December to 21 March; autumn, from 22 March to 21 June; winter, from 22 June to 21 September; and spring, from 22 September to 21 December.

The mortality of franciscana for the selected fisheries was determined as a stratified estimation by season for AOC and RPE. The two zones were analyzed separately due to observed differences in fishing strategies in relation to the number of fishing sets and average seasonal effort (see results). The confidence interval (CI: 2.5-97.5\%) of fishing effort by season was estimated from bootstrapbased confidence limits. Both in RPE and AOC, seasons vary in fishing strategy and effort conducted, and vessels concentrate in certain fishing grounds. These features gave us the possibility of extrapolating the data gathered to fishermen not surveyed at these localities, for they use the same fishing gears and grounds in each season. Thus, values were extrapolated for the remaining fraction of the fisheries studied, considering the monitored fishermen as a representative sample of all fishermen from such fisheries. Seasonal fishing effort employed by each fisherman and the by-catch probability were considered constant within each season. As for the FE and BPUE values, mortality estimations for RPE, AOC and the entire Uruguayan coast were calculated based on, and extrapolating to, the monitored fisheries in the second stage exclusively; no extrapolation was done for the other artisanal fisheries mentioned in the first stage. Differences were assessed with Mann-Whitney tests, as the data showed non-normality (Shapiro-test) and the significance was $p<0.05$. All analyses were carried out in $\mathrm{R}$ free software ( $\mathrm{R}$ Development Core Team, 2008).

\section{Results}

Franciscana interactions with the artisanal gillnet fisheries off the Uruguayan coast

During the first study stage, localities were identified 
where fishermen were familiar with franciscanas and where franciscanas were known to interact with the fishery. In the inner RPE, all the fishermen contacted in the localities of Carmelo, Colonia and Juan Lacaze (Figure 1) had never caught franciscanas in their fishing operations or even heard about this dolphin. At Kiyú and Playa Pascual, fishermen were aware of the species, but few fishermen operated in these localities, and they rarely caught franciscanas. Thus, these five fisheries were excluded from the second study stage. Despite Punta del Este (outer RPE) being an important fishery in the RPE, long-line was the most used fishing gear and no franciscana by-catch was recorded with it, thus this locality was also excluded in the second stage of the study. Along the AOC, franciscanas were reported to interact with all artisanal fisheries, but Punta del Diablo and Valizas were excluded due to the fisheries dynamics. In both areas, fishing takes place only during a few months per year (winter - spring) preventing an annual evaluation. At Punta del Diablo during recent years, red shrimps (Pleoticus muelleri) have become one of the main targeted species of the fishery. Although franciscana prey upon shrimps, the net used to catch red shrimps does not represent a problem for the species (Segura et al., 2008). At Valizas, the big sand barrier deposited in the mouth of the Valizas creek prevents fishing operations most of the year. In future studies, the exclusion of Punta del Diablo and Valizas needs to be re-evaluated, as changes in the fisheries dynamics are likely to occur. While we are aware that franciscana by-catch occurs in these fisheries, the dynamics did not allow an annual follow-up because our intermittent visits precluded the development of a relationship with the fishermen and the data collected was unreliable. In addition, during summer months, fishermen perform other activities that hinder the access to data.

\section{Fisheries description}

Based on the fishery characteristics at each locality, the reported interactions with franciscana, and logistic reasons, the localities selected for study during the second stage were: Pajas Blancas, San Luis, Piriápolis, La Paloma and Cabo Polonio (Figure 1, Table 2). Most fishermen showed willingness to cooperate with this study; however, there were differences among the fisheries of RPE and AOC.

\section{Río de la Plata estuary (RPE)}

In the RPE, nine out of 90-105 fishermen from three localities (Pajas Blancas/San Luis, Piriàpolis and Neptunia) recorded their fishing activities in the logbooks during the second stage. Pajas Blancas and San Luis are considered as a single fishery because fishermen (and often their families) usually move between both areas following the target species (i.e. the whitemouth croaker migration). In this fishery, the largest in this zone, where 80-90 boats operate during peak activity, seven fishermen were monitored using logbooks. 


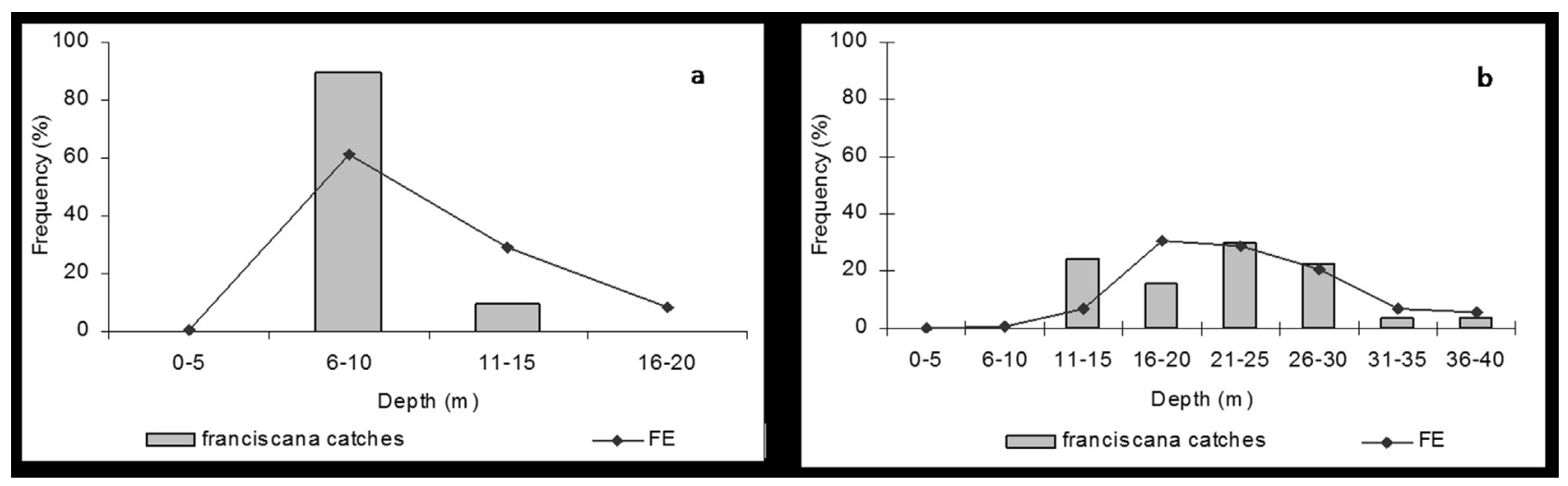

Figure 2. Linear fishing effort ( $\mathrm{FE}_{\mathrm{L}}: 1000 \mathrm{~m}$ of net set per hour) and franciscana dolphin catches by depth (m) in (a) Río de la Plata estuary (RPE) and (b) Atlantic Ocean coast (AOC) in 2006.

This represents only $8-9 \%$ of the total fleet, considering monthly and seasonal variations. Two fishermen were monitored in Piriápolis, where the number of boats operating varied between 10 and 15 (Table 2). During June 2006, all fishermen who worked with the logbooks moved to the fourth location, Neptunia (Figure 1: 7). This locality was not monitored during the first study stage and was not originally included in the second stage selection. However, Neptunia was added because of the size of the fleet (ca. 120 boats) arriving from nearly all fisheries of the RPE following the occurrence of great concentrations of whitemouth croaker. Such unpredictable movements of the fishermen along the Río de la Plata coast following the target species sometimes prevented us from contacting them on a monthly basis.

The main target species along the year is the whitemouth croaker, although in some seasons they also target other species like bluefish (Pomatomus saltatrix), Brazilian codling (Urophycis brasiliensis), parona leatherjacket (Parona signata), stripped weakfish (Cynoscion guatucupa), king weakfish (Macrodon ancylodon) and Brazilian menhaden (Brevoortia aurea). Most cases in which gillnets remained only few minutes in the water were due to the use of echo sounding equipment (Table 2). Such equipment enables them to locate the school of fish and set the nets accurately in position and time.

\section{Atlantic Ocean coast (AOC)}

A total of 17 fishermen were contacted in this zone, where fishermen homes are stable and the monthly follow up of activities was easier than in RPE. Two localities were visited: La Paloma, where 14 fishermen (i.e. $50 \%$ of the total fishery) were contacted, and Cabo Polonio, where all fishermen were visited $(n=3$; Table 2). All fishermen recorded every fishing event in their logbooks and considered it a good method for having their own fishing records.

In these fisheries the main target species during winterautumn was the narrownose smooth-hound (Mustelus schmitti), followed by sciaenid fishes such as the whitemouth croaker and the stripped weakfish. During spring-summer the fishery targeted mainly the angel sharks (Squatina spp.), followed by tope sharks (Galeorhinus galeus), sand tiger sharks (Carcharias taurus), sandbar sharks (Carcharhinus plumbeus) and hammerhead sharks (Sphyrna sp.) (see Table 2).

\section{Franciscana by-catch}

In 2006, considering the whole study area, 80 franciscanas were reported as incidentally captured and in all cases, they were caught dead. As data were not complete for all fishing trips (e.g. number of franciscanas caught per depth or mesh size), the number of captures used in the analyses varies according to the different variables considered.

In RPE, 10 franciscanas were incidentally caught; nine of them in autumn and one in summer (Table 3). The FE was higher in autumn (65\%) (Table 3), within $9 \mathrm{~km}$ from the coast (85\%) where all recorded franciscanas were caught. The depth where most $(61 \%)$ of the $\mathrm{FE}_{\mathrm{L}}$ was employed ranged from 6 to $10 \mathrm{~m}$, and accounted for $90 \%$ of the recorded bycatch (Figure 2a). Most (92\%) FE $\mathrm{F}_{\mathrm{L}}$ occurred when using nets of mesh sizes of $10-12 \mathrm{~cm}$, in which all recorded franciscanas were incidentally caught (Table 4).

In AOC, the by-catch of 70 franciscanas was recorded and most of them occurred in spring $(47.1 \%)$, followed by summer $(24.3 \%)$, winter $(20 \%)$ and autumn $(8.6 \%)$. In this area the $\mathrm{FE}_{\mathrm{L}}$ was higher in summer (56\%) (Table 3), when sharks are the target species and nets used have a minimum of $18 \mathrm{~cm}$ of stretched mesh size, and are set close to shore. Most fishing effort (78\%) took place within $9 \mathrm{~km}$ of shore, where $59(84 \%)$ of the recorded franciscanas were caught. The $\mathrm{FE}_{\mathrm{L}}$ was similar in depths of $16-20 \mathrm{~m}$ and $21-25 \mathrm{~m}$ ( $31 \%$ and $29 \%$, respectively); however, the greatest total number of franciscanas reported $(n=17$; $30 \%)$ was recorded in depths of 21-25m $(\mathrm{H}=5.46$; $\mathrm{p}<0.05)$ (Figure $2 \mathrm{~b}$ ). $\mathrm{FE}_{\mathrm{L}}$ was greater with $10-12 \mathrm{~cm}$ mesh size nets $(26 \%)$; however, franciscana by-catch was greatest $(n=30$ or $43 \%$ ) when using nets of $18-20 \mathrm{~cm}$ stretched mesh size, which accounted for only $22 \%$ of the total $\mathrm{FE}_{\mathrm{L}}$ (Table 4 ). 
Table 4. Number of franciscanas incidentally caught $(\mathrm{C})$, total linear fishing effort ( $\mathrm{FE}_{\mathrm{L}^{\prime}}$ expressed as $1000 \mathrm{~m}$ of net set per hour) and bycatch per unit of effort BPUE $_{\mathrm{L}}$, expressed as number of franciscanas caught per 1000m of net per hour) according to the mesh size (in centimetres) used by the artisanal gillnet fishery in Río de la Plata estuary (RPE) and Atlantic Ocean coast (AOC) during 2006.

\begin{tabular}{|c|c|c|c|c|c|c|}
\hline \multirow{2}{*}{$\begin{array}{c}\text { MESH SIZE } \\
(\mathrm{cm})\end{array}$} & \multirow{2}{*}{$\begin{array}{c}\text { RPE } \\
\text { C }\end{array}$} & \multicolumn{5}{|c|}{$\mathrm{AOC}$} \\
\hline & & $\mathrm{FE}_{\mathrm{L}}$ & $\mathrm{BPUE}_{\mathrm{L}}$ & $\mathrm{C}$ & $\mathrm{FE}_{\mathrm{L}}$ & $\mathrm{BPUE}_{\mathrm{L}}$ \\
\hline $7-9$ & 0 & 132.36 & 0.0000 & 0 & - & - \\
\hline $10-12$ & 10 & 1516.09 & 0.0066 & 19 & 10030.74 & 0.0019 \\
\hline $13-16$ & 0 & - & - & 4 & 1066.86 & 0.0037 \\
\hline $18-20$ & 0 & - & - & 30 & 8473.47 & 0.0034 \\
\hline $22-24$ & 0 & - & - & 7 & 7853.16 & 0.0010 \\
\hline $26-30$ & 0 & - & - & 0 & 3895.95 & 0.0000 \\
\hline$>32$ & 0 & - & - & 10 & 7344.66 & 0.0014 \\
\hline
\end{tabular}

The annual $\mathrm{BPUE}_{\mathrm{L}}$ for the entire Uruguayan coast was $0.0020(\mathrm{SD}=0.0007)$ franciscanas per $1000 \mathrm{~m}$ per hour, but there was an inverse seasonal relationship between $\mathrm{FE}_{\mathrm{L}}$ and $\mathrm{BPUE}_{\mathrm{L}}$ (Table 3), with spring having the greatest $\mathrm{BPUE}_{\mathrm{L}}$ and the least $\mathrm{FE}_{\mathrm{L}}$; while summer had the greatest fishing effort and the smallest BPUE $\left(\mathrm{FE}_{\mathrm{L}}: \mathrm{H}=5.95 ; \mathrm{P}=0.014\right)$. The annual $\mathrm{BPUE}_{\mathrm{L}}$ (as franciscanas per $1000 \mathrm{~m}$ per hour) for the RPE was $0.0061(\mathrm{SD}=0.0009)$ and for the AOC was $0.0018(\mathrm{SD}=$ 0.00067). In the RPE, the BPUE $E_{\mathrm{L}}$ was greatest in the season with the highest $\mathrm{FE}_{\mathrm{L}}$, while in AOC the highest BPUE $_{\mathrm{L}}$ was reported during the season with the least $\mathrm{FE}_{\mathrm{L}}$ (Table 3).

When the fishing effort was based on fishing events $\left(1000 \mathrm{~m}\right.$ per set; $\left.\mathrm{FE}_{\mathrm{S}}\right)$, the annual $\mathrm{BPUE}_{\mathrm{S}}$ for the entire Uruguayan coast was $0.0286(\mathrm{SD}=0.0177)$ franciscanas per $1000 \mathrm{~m}$ per set. This measure of $\mathrm{FE}_{\mathrm{S}}$ varied between seasons $(\mathrm{P}<0.05$ in all cases $)$ and was greatest during winter, while the greatest $\mathrm{BPUE}_{\mathrm{S}}$ occurred in spring

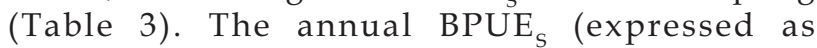
franciscanas per $1000 \mathrm{~m}$ per set) was $0.0462(\mathrm{SD}=$ $0.0094)$ for the RPE and $0.0272(S D=0.0080)$ for the AOC. Number of fishing events recorded, $\mathrm{FE}_{\mathrm{S}}$ and $\mathrm{BPUE}_{\mathrm{S}}$ per area and season are shown in Table 3 .

By-catch of other species such as Phocoena spinipinnis, Arctocephalus australis, Otaria flavescens, Chelonia mydas, Dermochelys coriacea and Caretta caretta were recorded occasionally.

\section{Mortality}

From the recorded by-catch, the estimated mean annual mortality of franciscanas, calculated as the sum of the mortalities per area and season, in the surveyed Uruguayan fisheries was 289 (CI: 266-350) individuals in 2006. In the AOC and in the RPE, the mean estimated mortality was 195 (CI: 181-232) and 94 (CI: 85-118) franciscanas, respectively. Seasonal and annual values of mortality for the RPE, AOC and the Uruguayan coast are shown in Table 5.

\section{Discussion}

The first study stage was important for understanding the dynamics of the fishery and to approach fishermen and improve their trust, so data collected during the second stage would be more reliable. Although during the first stage of this work the collaboration of individual fishermen interviewed varied, the committed work of some fishermen encouraged others to participate. The strategy of work, where researchers emphasized the importance of proper recording of data on each visit and responded to questions and demands of the fishermen led to a strong commitment between the two parts. It also turned into a sense of ownership and responsibility by the fishermen for being a fundamental part of the research as they were the ones who collected the data onboard. Hence, in the second stage, most fishermen recorded data of their fishing events in the logbook on a continuous basis. A priori, records of franciscanas incidentally caught may be thought of as being underreported due to the species' conservation status and possible penalizations over its capture. Nevertheless, given that this study was neither conducted nor directed by any fiscal organization, and given the approach used, data provided by fishermen are considered as trustworthy. Further, providing the fishermen with cameras resulted in a good method to encourage them to become more involved with the study. In both zones cameras had good acceptance, fishermen took pictures not only of franciscanas but also of several situations of their work, and the pictures helped in generating a more relaxed conversation and increasing their enthusiasm about our monthly visits as well.

The use of logbooks differed between the two areas: in the AOC fishermen showed more willingness to cooperate, resulting in a greater number of logbooks completed and a greater representation of the entire fleet operating in the area. The difference in support and commitment to this work might be related to differences in social, economic, and cultural circumstances between areas. 


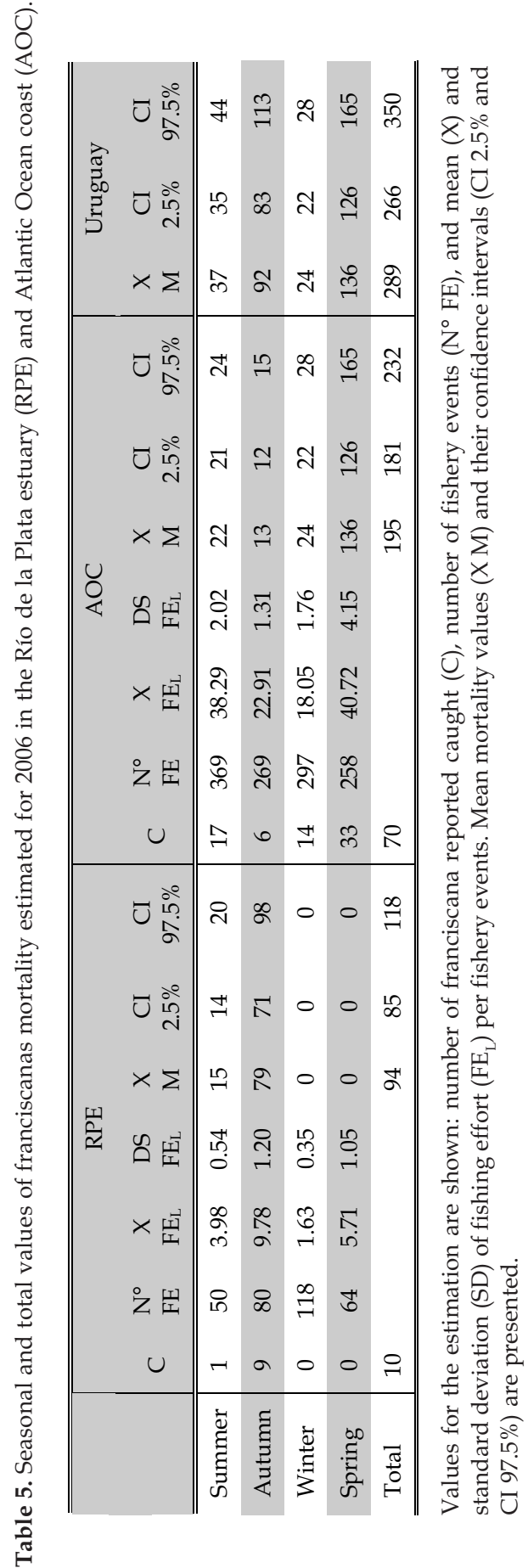

In the RPE, and particularly in Pajas Blancas/San Luis (the largest fishing community of the region), poverty is widespread. This community is far from having their basic needs covered (food, health, education, etc.), and houses are precariously built on the sand. Most homes are not stable. When fishermen follow the migration of the whitemouth croaker, some families are temporarily broken apart or the whole family moves together at least twice a year. Therefore, it is difficult to motivate fishermen to commit to the research and develop an awareness of their own activity, at least in the short term. The difficulties in establishing connections each month and maintaining continuity of logbook reporting makes RPE a challenging area to study. In this region, neither the number of franciscanas caught nor the fishing effort recorded was high. However, records increased as time passed, suggesting that the fishermen's confidence may have improved through time and that the overall by-catch may have been underestimated. Long-term studies are needed to better understand the magnitude of franciscana interactions with this fishery.

In the AOC the overall social and economic situation is modest, but it varies among fishermen, with some living in extreme poverty. Homes are stable, and fishermen work in the same locality all year round, making it easier to contact them systematically and increase their trust towards the research. Fishermen with higher educational levels consider it important to get involved with scientific research, and regard it as valuable for their work and for the conservation of the species. Such a perspective is very important for the continuity of the research, since it has a positive influence on other fishermen.

\section{Franciscana by-catch}

During 2006, 80 franciscanas were recorded caught along the Uruguayan coast, providing an annual mortality estimate of 289 (CI: 266-350) franciscanas in the fisheries surveyed, with the greatest by-catch in the AOC zone. This study represents the first one including data on interaction in the estuarine Uruguayan coast. Recorded mortality for the AOC was lower than the values obtained during 1970-1990, but slightly higher than those obtained for 1993-1994 (Praderi, 1997). Because there were no data of fishing effort during 2005, the BPUE (linear and per set) was estimated only for 2006, and the incidental catch of franciscana dolphin is not comparable for both stages of our study in the Uruguayan coast. Moreover, these results are based on the first two years of monitoring after a twelve-year gap of systematic studies. Hence, it is necessary to continue and intensify data recording to verify apparent trends.

The franciscana is restricted to coastal areas, between the coastline and the $40-60 \mathrm{~m}$ isobath, and up to $55 \mathrm{~km}$ off the coast (Pinedo et al., 1989; Danilewicz et al., 2002). In this study, $25.4 \%$ of the recorded captures occurred at depths of $21-25 \mathrm{~m}$, but four captures were recorded between 31 and $37 \mathrm{~m}$ depth. 
In the RPE, most captures of franciscana dolphins were recorded during autumn, when recorded fishing effort was greater than in other seasons because soaking times of the nets were longer (up to $37.5 \mathrm{hs}$ ). The BPUE $\mathrm{L}_{\mathrm{L}}$ value was greater in autumn, and both the fishing effort and the number of franciscanas caught were greatest. In AOC, most franciscanas were captured during spring, one of the seasons in which the fishing vessels target large sharks (e.g. Squatina sp., Galeorhinus galeus, Carcharhinus sp.) with nets of stretched mesh sizes larger than $18 \mathrm{~cm}$, set within $9 \mathrm{~km}$ off the coast and for up to 90 days (Table 2). This is consistent with the findings of Praderi (1997) based on their 20-year study, which also identified the greatest mortality of franciscana during spring and summer (from November to February), when shark fisheries used nets of large stretched mesh size. During our study, shark fishing led to increased effort during summer (roughly four times the effort during spring), but franciscana by-catch during spring was about twice that of summer. This may be due to fleet characteristics and/or the behaviour and ecology of franciscana (Bordino et al., 1999; Bordino et al., 2002), not analyzed herein.

\section{BPUE values}

In this paper we describe two BPUE values related to fishing effort units (Table 3). However, due to the high variability in fishery dynamics found, within and between fisheries, in relation to soak time and frequency of fishing set, we suggest that the BPUE $\mathrm{L}_{\mathrm{L}}$ is the more accurate index for this study. Nevertheless in order to compare with values reported for the rest of the species distribution, a value per set (fishing event) had to be calculated. When using the $\mathrm{FE}_{\mathrm{S}}$, there is an uncertainty of the real fishing effort because the time nets are set can vary considerably among fishermen, target species, season, and even among areas. For such reasons, we believe it is important to characterize the dynamics of the fisheries monitored in this study. For example in AOC, nets targeting shark species during spring-summer are set over periods ranging from one week to three months, but fishermen cannot check their nets daily. So, if fishing effort is expressed in units of $1000 \mathrm{~m}$ of net per hour $\left(\mathrm{FE}_{\mathrm{L}}\right)$ the greatest value is obtained for summer, but when it is considered in units of $1000 \mathrm{~m}$ of nets per set $\left(\mathrm{FE}_{\mathrm{S}}\right)$, the greatest value is obtained for winter. Thus, fishing effort varies if the total time (hours) a nets is set is considered, rather than simply counting fishing events.

In Uruguay there were two previously reported values of BPUE based only on records from AOC (franciscanas per $1000 \mathrm{~m}$ of net per set) (Crespo et al., 1986; Praderi et al., 1989). The $\mathrm{BPUE}_{\mathrm{S}}$ value obtained for the surveyed area during 2006 is higher than those previously reported, despite certain statistical uncertainty, showing a possible increasing trend since 1975 (Table 1). The estimate presented in this study is one order of magnitude greater than the values reported for the AOC during 1975-1978, 1980-1982, and based on the 20-year review (1974-1994). Although the total number of estimated captures

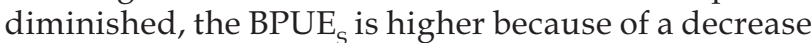
in fishing effort.

In comparison with estimates from Brazil, the $\mathrm{BPUE}_{\mathrm{S}}$ values reported in this study are greater than those reported by Di Beneditto (2003) for Northern Rio de Janeiro and by Secchi et al. (1997) for Rio Grande/Rio Grande do Sul. They are similar to those reported by Secchi et al. (2004) for the same area, but lower than rates reported by Ott et al. (2000) for Torres and Tramandai/ Rio Grande do Sul. Values recorded for South and North of Buenos Aires Province in Argentina (Corcuera et al., 2000; Cappozzo et al., 2000) are higher than the one reported herein (Table 6).

Table 6. By-catch per unit of effort (BPUE) of franciscana dolphin in the artisanal gillnet fishery of the different localities of the region.

\begin{tabular}{lcl}
\hline \hline LOCALITY & $\begin{array}{c}\text { BPUE (FRANCISCANAS PER } \\
\text { 1000m OF NET PER DAY) }\end{array}$ & \multicolumn{1}{c}{ SOURCE } \\
\hline \hline North of Rio de Janeiro (Brazil) & 0.015 & Di Beneditto, 2003 \\
Torres and Tramandai / Rio Grande do Sul (Brazil) & 0.054 & $\begin{array}{l}\text { Ott, 1998; Ott } \text { et al., 2000 } \\
\text { Moreno } \text { et al., 2000 }\end{array}$ \\
Rio Grande/ Rio Grande do Sul (Brazil) & 0.088 & Secchi et al., 1997 \\
& 0.0066 & Secchi et al., 2004 \\
Atlantic coast, Rocha (Uruguay) & $0.0119-0.0294$ & Ott et al., 2000 \\
Atlantic coast, Rocha (Uruguay) & 0.0064 & Crespo et al., 1986 \\
Atlantic coast and Rio de la Plata Estuary (Uruguay) & $0.0025-0.0055$ & This study \\
North of Buenos Aires Province (Argentina) & 0.0286 & Corcuera et al., 2000 \\
& 0.2161 & Cappozzo et al., 2000 \\
South of Buenos Aires Province (Argentina) & 0.4289 & Cappozzo et al., 2000 \\
\hline \hline
\end{tabular}

Data are presented as linear values (1000m of net set per day). 


\section{Final considerations}

Along the Uruguayan coast, artisanal fisheries operate within the range of the franciscana dolphin, highlighting this species' vulnerability. This is the first by-catch study to include estuarine Uruguayan waters and to estimate mortality values within them. Also, we present effort and by-catch rates using two different measures. Our results update the by-catch data for Uruguay, and make a substantial contribution to the studies of mortality of franciscanas, particularly in the Franciscana Management Area III (FMA III) (Secchi and Wang, 2003 ${ }^{11}$ ).

A long-term monitoring plan in the fishing localities studied is essential for conservation and would enable enhancing links with fishermen. Finally, we recommend that future evaluations should be supported by abundance estimations in the study area, allowing for a more precise analysis of the impacts of by-catch on the species within FMAIII. The information reported herein is the first step towards generating relevant information for establishing management measures and marine protected areas in Uruguay.

\section{Acknowledgements}

We are indebted to the fishermen, and their families, who are part of this work and provided invaluable assistance in data collection. We thank Mariana Piedra, Alejandra de Giorgi and Verónica Iriarte for collaborating in the beginnings of this project, and Philip Miller for field assistance. We are grateful to Marila Lázaro for introducing the franciscana to most of us and for encouragement to start studying it. We also thank Bettina Tassino (Facultad de Ciencias - UDELAR), Ignacio Moreno and Daniel Danilewicz (GEMARS) who reviewed an early version of this project. We are very grateful to Enrique Crespo and Eduardo Secchi for their support and significant contributions to our work and the manuscript. Thanks to Javier Klaich and to Susana Pedraza for their help with statistics. The National Directorate of Aquatic Resources of Uruguay (DI.NA.R.A.) provided logistic support. This research was supported by grants from Yaqu-pacha and The Rufford Maurice Laing Foundation. Also, we thank the two anonymous referees for their corrections and comments that helped us improve the manuscript. Finally, we dedicate this work to Ricardo Praderi, the pioneer researcher on franciscana, who is always willing to cooperate.

\section{References}

Acha, E.M., Mianzan, H., Lasta, C.A. And Guerrero, R.A. (1999) Estuarine spawning of the whitemouth croaker Micropogonias furnieri (Pisces: Scianidae), in the Río de la Plata, Argentina. Marine and Freshwater Research 50: 57-65.
Acuña, A., Arena, G., Berois, N., Mantero, G., Masello, A., Nión, H., RetTA, S. ANd Rodríguez, M. (1996) The croaker (Micropogonias furnieri): biological cycle and fisheries in the Rio de la Plata and its oceanic front. Pages 185-222 in Wells, P.G., Daborn, G.R. (Eds) The Rio de la Plata. An environmental overview. An Ecoplata Project Background Report. Dalhousie University, Halifax, Nova Scotia, Canada.

Bordino, P., Thompson, G. y IÑIguez, M. (1999) Ecology and behavior of the franciscana dolphin Pontoporia blainvillei in Bahía Anegada, Argentina. The Journal of Cetacean Research and Management. 1(2): 213-222.

Bordino, P., SicILIANO, S., BASTIDA, R. AND CREMER, M. (2002) Report of the working group on distribution and behavior. The Latin American Journal of Aquatic Mammals (Special Issue) 1: 21-23.

Boschi, E.E. (1988) El Ecosistema Estuarial del Río de la Plata (Argentina y Uruguay). Anales del Instituto de Ciencias del Mar y Limnología de la Universidad Nacional Autónoma de México. 15(2): 159-182.

BrownelL, R.L. Jr. (1975) Progress report on the biology of the Franciscana Dolphin, Pontoporia blainvillei, in Uruguayan waters. Journal of the Fisheries Research Board of Canada 32(7): 1073-1078.

Crespo, E.A., Perez Macri, G. and Praderi, R. (1986) Estado actual de la población de Franciscana, Pontoporia blainvillei en las costas uruguayas. Pages 92-105 in CASTello, H.P. (Ed.) Actas I Reunión de Trabajo de Expertos en Mamíferos Acuáticos de América del Sur, Buenos Aires.

Danilewicz, D., Rosas, F., Bastida, R., Morigo, J., Muelbert, M., Rodríguez, D., Lailson Brito, Jr. J., Ruoppolo, V., Ramos, R., Bassoi, M., Ott, P.H., CaOn, B., Monteiro da Rocha, A., CaAoDiAS, J.L. AND SECCHI, E.R. (2002) Report of the working group on biology and ecology. The Latin American Journal of Aquatic Mammals (Special Issue) 1: 25-42.

Di BeneditTo, A.P.M. (2003) Interactions between gillnet fisheries and small cetaceans in northern Rio de Janeiro, Brazil: 20012002. The Latin American Journal of Aquatic Mammals 2: 79-86.

EFRON, B., AND TibShIRANI, R.J. (1993) An introduction to the bootstrap. London, U.K.: Chapman \& Hall.

Guerrero, R.A., Acha, E.M., Framiñan, M.B. and Lasta, C.A. (1997) Physical oceanography of the Río de la Plata Estuary, Argentina. Continental Shelf Research 17(7): 727-742.

Jaureguizar, A.J., Menni, R., Bremec, C., Mianzan, H. and Lasta, C. (2003) Fish assemblage patterns in the Río de la Plata Estuary. Estuarine Coastal and Shelf Science 56: 921-933.

KINAS, P.G. (2002) The impact of incidental kills by gillnets on the franciscana dolphin (Pontoporia blainvillei) in southern Brazil. Bulletin of Marine Science 70: 409-421.

Lopes, R.M., Katsuragawa, M., Dias, J.F., Montúm, A., Muelbert, J., GorRI, C. AND BrandinI, F.P. (2006) Zooplankton and Ichtioplankton Distribution on the Southern Brazilian Shelf: an Overview. Scientia Marina 70(2): 189-202.

MacchI, G.J. AND AcHA, M.E. (2000) Spawning frequency and batch fecundity of Brazilian menhaden, Brevoortia aurea, in the Río de la Plata Estuary off Argentina and Uruguay. Fishery Bulletin 98: 283-289.

\footnotetext{
${ }^{11}$ Secchi, E.R. \& Wang, J.Y. 2003. Pontoporia blainvillei (Rio Grande do Sul/Uruguay subpopulation). In: IUCN 2009. IUCN Red List of Threatened Species. Available at: <www.iucnredlist.org>.
} 
Macchi, G.J., Acha, M.E. And Lasta, C.A. (1996) Desove y fecundidad de la corvina rubia Micropogonias furnieri (Desmarest, 1823) del estuario del Río de la Plata, Argentina. Boletín del Instituto Español de Oceanografía 12: 99-113.

MacchI, G.J., Acha, M.E. And Militelli, M.I. (2003) Seasonal egg production of whitemouth croaker (Micropogonias furnieri) in the Río de la Plata estuary, Argentina-Uruguay. Fishery Bulletin 101: 332-342.

Mianzan, H., Lasta, C., Acha, E., Guerrero, R., Macchi, G. and Bremec, C.B. (2001) The Río de la Plata Estuary, ArgentinaUruguay. Pages 185-204 in Seeliger, U., De Lacerda, L.D. AND KJERVE, B. (Eds) Ecological studies: coastal marine ecosystems of Latin America. Springer-Verlag, Berlin.

Norbis, W., Paesch, L., Verocai, J. and Villamarín, G. (1992) Cambios en la estructura de la población de corvina rubia (Micropogonias furnieri) capturada en la pesquería artesanal de Pajas Blancas. Montevideo, Uruguay. Frente Marítimo 11:37-45.

Norbis, W. AND Verocal J. (2001) Analysis of the population structure of croacker captured by the artisanal fishery of Pajas Blancas. Pages 177-190 in Vizziano, D., Puig, P., Mesones, C. And Nagy, G. (Eds) The Rio de la Plata. Research to Manage the Environment, Fish Resources and the Fishery in the Saline Front. Ecoplata Program. Montevideo, Uruguay.

Ortega, L. AND Martinez, A. (2007) Multiannual and seasonal variability of water masses and fronts over the Uruguayan shelf. Journal of Coastal Research 23: 625-629.

OtT, P.H., SeCchi, E., Moreno, I.B., Danilewicz, D., CRespo, E.A., Bordino, P., Ramos, R., Di Beneditto, A.P., Bertozzi, C., Bastida, R., Zanelatto, R., Pérez, J. and KinAs, P.G. (2002) Report of the Working Group on Fishery Interactions. The Latin American Journal of Aquatic Mammals (Special Issue) 1: 55-64.

Pilleri, G. (1971) On the La Plata dolphin, Pontoporia blainvillei off the Uruguayan coasts. Investigations Cetacea 3: 69-73.

Pinedo, M.C., Praderi, R. and Brownell, R.L. Jr. (1989) Review of the biology and status of the franciscana Pontoporia blainvillei. Pages 46-51 in Perrin, W.F., Brownell, R.L. JR., Kaiya, Z. AND JiANKANG, L. (Eds) Biology and Conservation of the River Dolphins. Occ. Pap. IUCN SSC 3 Gland, Switzerland.

Piola, A.R., Campos, E.J.D., Möller, O.O., Charo, M. and Martínez, C. (2000) Subtropical Shelf Front off eastern South America. Journal of Geophysical Research 105 (3): 6565-6578.

Praderi, R., Pinedo, M.C. ANd CRespo, E.A. (1989) Conservation and management of Pontoporia blainvillei in Uruguay, Brazil and Argentina. Pages 52-56 in Perrin, W.F., Brownell, R.L., KatyA, Z. AND Jiankang, L. (Eds) Biology and Conservation of the River Dolphins. Occasional Papers. IUCN SSC 3: Gland, Switzerland.
R Development Core Team (2008) R: A language and environment for statistical computing. R Foundation for Statistical Computing, Vienna, Austria. ISBN 3-900051-07-0. Available at: http://www.R-project.org.

SECCHI, E.R. (1999) Taxa de crescimento potencial intrínseco de um estoque de franciscanas, Pontoporia blainvillei (Gervais and D'Orbigny, 1844) (Cetacea, Pontoporiidae) sob o impacto da pesca costeira de emalhe. Master Thesis, Fundação Universidade Federal do Rio Grande, Rio Grande, Brazil

Secchi, E.R., Zerbini, A.N., Bassoi, M., Dalla Rosa, L., Moller, L.M. AND RocCHA-CAMPOS, C.C. (1997) Mortality of franciscanas, Pontoporia blainvillei, in coastal gillnets in southern Brazil: 19941995. Report of the International Whaling Commission 47: 653-658.

Secchi, E.R. and Wang, J.Y. (2002) Assessment of the conservation status of a franciscana (Pontoporia blainvillei) stock in the Franciscana Management Area III following the IUCN Red List process. The Latin American Journal of Aquatic Mammals (Special Issue) 1: 183-190.

Secchi, E.R., Ott, P.H. and Danilewicz, D. (2002) Report of the Fourth Workshop for the Coordinated Research and Conservation of the Franciscana Dolphin (Pontoporia blainvillei) in the Western South Atlantic. The Latin American Journal of Aquatic Mammals (Special Issue) 1: 11-20.

Secchi, E.R., KinAs, P.G. And Muelbert, M. (2004) Incidental catches of franciscana in coastal gillnet fisheries in the Franciscana Management Area III: period 1999-2000. The Latin American Journal of Aquatic Mammals (Special Issue) 1: 61-68.

Secchi, E.R., Ott, P.H. and Danilewicz, D.S. (2003) Effects of fishing by-catch and conservation status of the franciscana dolphin, Pontoporia blainvillei. Pages 174-191 in Gales, N., Hindell, M. and Kirkwood, R. (Eds) Marine mammals: fisheries, tourism and management issues. CSIRO Publishing, Collingwood, Australia

Segura, A.M., Delgado, E.A. and Carranza, A (2008) La pesquería de langostino en Punta Del Diablo (Uruguay): un primer acercamiento. Pan-American Journal of Aquatic Sciences 3(3): 232-236.

VAN ERP, I. (1969) In quest of the La Plata dolphin. Pacific Discovery 22: 18-24p.

Vizziano, D., Saona, G., Franco, J. and Nagy, G. (2001) Environmental characterization of the spawning area of the white croaker Micropogonias furnieri in the frontal zone of the Río de la Plata. Pages 113-124 in: D. Vizziano, P. Puig, C. Mesones and G. J. Nagy (Eds), The Río de la Plata. Research to Manage the Environment, Fish Resources and the Fishery in the Saline Front. Ecoplata Program, Montevideo, Uruguay. 